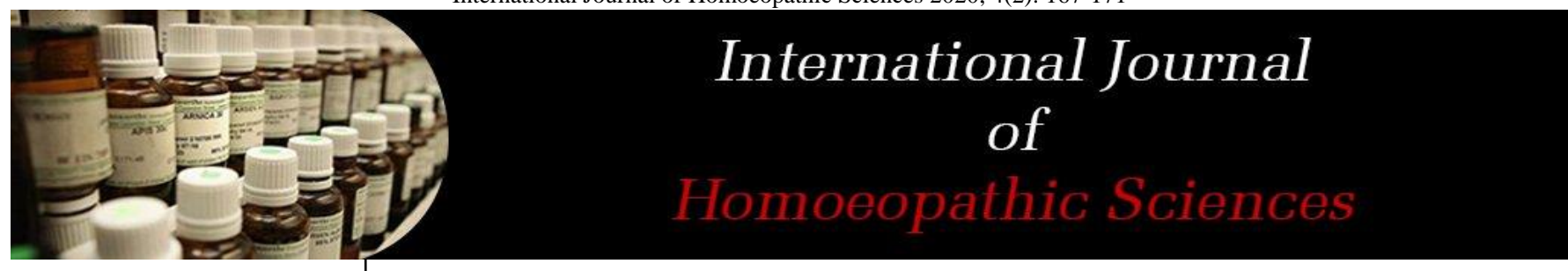

E-ISSN: $2616-4493$

P-ISSN: 2616-4485

www.homoeopathicjournal.com

IJHS 2020; 4(2): 167-171

Received: 13-02-2020

Accepted: 15-03-2020

Dr. Bhavani R

Final Year Public Health,

Department of Epidemiology,

The Tamil Nadu Dr. MGR

Medical University, Chennai

Tamil Nadu, India

Dr. Kalpana S

Research Officer,

Department of Epidemiology,

The Tamil Nadu Dr. MGR

Medical University, Chennai

Tamil Nadu, India
Corresponding Author:

Dr. Bhavani R

Final Year Public Health,

Department of Epidemiology,

The Tamil Nadu Dr. MGR

Medical University, Chennai

Tamil Nadu, Indi

\section{Homeopathy: Treatment seeking behavior among semi-urban population in Chennai}

\section{Dr. Bhavani $R$ and Dr. Kalpana $S$}

DOI: $\underline{\text { https://doi.org/10.33545/26164485.2020.v4.i2c.165 }}$

\begin{abstract}
:
Aims and objective: To assess the Treatment seeking behavior of homeopathy among 30-55 age group population in semi urban Chennai.

Settings and design: A community-based, cross-sectional study was conducted from March 2019 To September 2019 in the semi-urban area of Poonamalle, Chennai.

Materials and Methods: A total of 220 study participants were selected by cluster sampling and between the age group of $30-55$ were interviewed by semi-structure questionnaire.

Results: The finding of the study shows that majorities (31\%) of respondents were graduated. Socioeconomically, the majority of them belong to the lower-middle-class group. Most of the participants were housewives. The majority of respondents know about homeopathy via treatments of friends and family (39\%), TV \& Newspaper (39\%).Minimal number of the study people $(44.1 \%)$ believed homeopathy medicine is working and it having curative power. But the majority of study peoples replied that homeopathic treatment system is not very common in a few public, indicating the need for more public awareness on it. Majority of study people (70.5\%) not taking homeopathy due to lack of awareness of homeopathy treatment, lack of government hospital department for homeopathy treatment and non-availability of homeopathy pharmacy.

Conclusion: Major lack of awareness is due to lack of availability homeopathy clinics and pharmacies in rural and semi-urban areas. So, increasing the availability helpful for homeopathy easily reaches every corner of the rural and semi-urban area. Every homeopath should take major responsibility to create awareness and helps the people to get better treatment in homeopathy.
\end{abstract}

Keywords: Homeopathy, semi urban, awareness, homeopathy pharmacy

\section{Introduction}

The Indian Systems of Medicine and Homoeopathy (ISM\&H) were given an independent identity in the Ministry of Health and Family Welfare in 1995 by creating a separate Department of Ayurveda, Yoga and Naturopathy, Unani, Siddha and Homoeopathy (AYUSH) in November $2003^{[1]}$.

The ancient Indian systems of medicine and homeopathy (ISM\&H) lay great emphasis on prevention of disease and promotion of health. Ayurveda, yoga, Unani, Siddha, homeopathy and naturopathy comprise the acronym (AYUSH) used to refer to alternative medical systems that are being practiced in India ${ }^{[2]}$

Traditional and Complementary Medicine is a method that can enrich, strengthen the public health system and improve the quality of life; contribute to the quality of economic and social development; improve the health and development of local communities; safe guard cultural differences; focus attention on health care centers intended as physical, mental, spiritual and social well-being of people, nature and environment ${ }^{[2]}$.

Since origin, it has a patient centered approach and a holistic focus on health care instead of a disease-centered approach of conventional medicine. Homeopathy is one of the most frequently used and controversial systems of complementary and alternative medicine.

It is based on the 'principle of similar', whereby highly diluted preparations of substances that cause symptoms in healthy individuals are used to stimulate healing in patients who have similar symptoms when ill. When a single homeopathic remedy is selected based on a patient's total symptom picture, it is called 'classical' homeopathy.

Homeopathy system is one of the safest systems of treatment for children's, all age group and both sex and without side effect. Homeopathy treatments not only cure the physical symptom and also cure the mind suffering of the patient. The effectiveness of homeopathic drugs are claimed to be very high while the cost and side effects of the same is very low 
Probably this is the reason why homeopathy has greater demand in countries such as India with low GPD(3) There is lack of studies assessing the Treatment seeking behavior of homeopathy in general population. Hence this study was taken to find out health seeking behavior of homeopathy.

\section{Materials and Methods}

\section{Study design, period and area}

This community-based cross-sectional study was conducted from March 2019 To September 2019 in the semi-urban area of Poonamalle, Chennai.

\section{Sample size and technique}

Based on previous study, the sample size was calculated as 220. With help of cluster sampling, Poonamalle was separated into small clusters. Through simple random sampling method study participants were selected from clusters of poonamalle.

\section{Selection criteria}

People who residing in study area, both sex and age criteria is 30-55 age group people were considered. People who are not willing to participate in the study were excluded from study.

\section{Procedure}

The study was approved by Institutional Ethics Committee of The Tamilnadu Dr. MGR medical university, Chennai. The study participants were interviewed, based on the selection criteria, the study participants were selected, and written informed consent was obtained from all the participants. The data were collected using the Semi structure questionnaire section A (Demographic Details) and section B (knowledge assessing questions).

\section{Statistical analysis}

The data were tabulated using MS Excel sheet and analysis was done using percentages, rates, and ratios. Chi-square test was used to find the association between attributes

\section{Results}

Analysis and Interpretation:

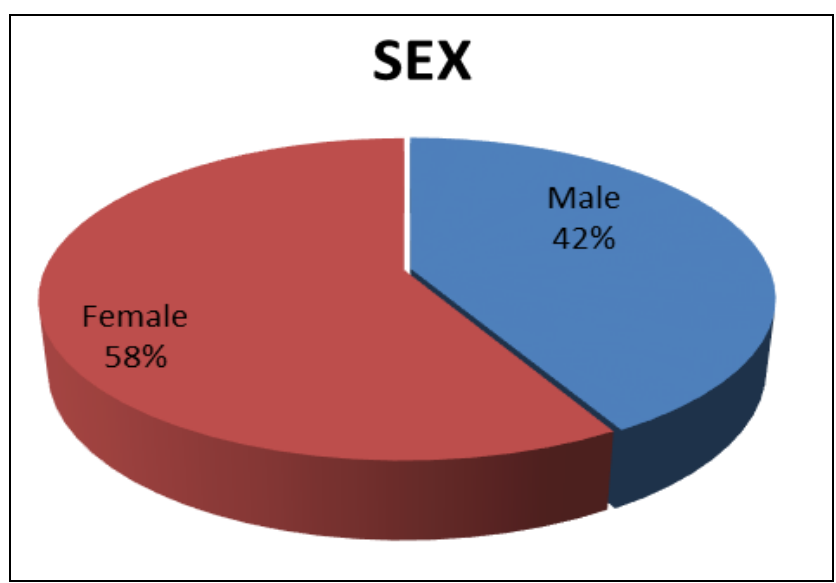

Fig 1: Shows Gender distribution

Figure 1 showed as 220 participants were added in this study. Among them 58\% are Female and $42 \%$ are male.

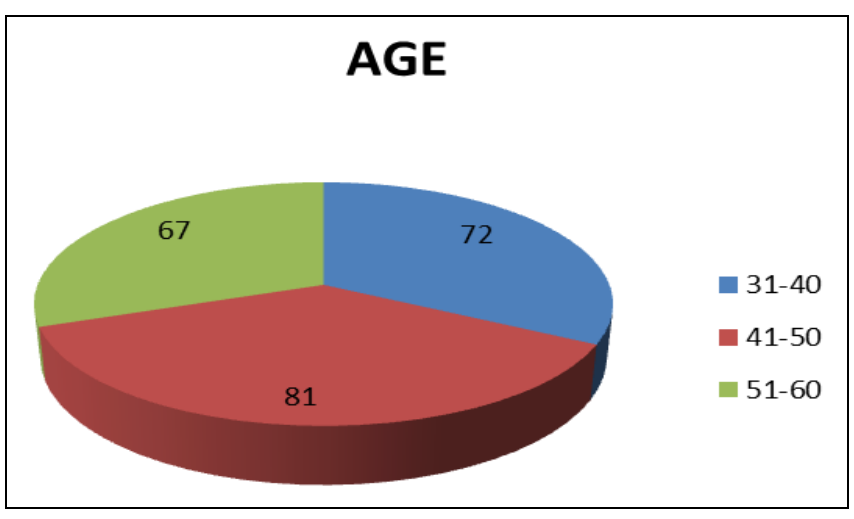

Fig 2: Shows Age distribution

Figure 2 showed as 72 participants comes under the 31-40 age group, 81 participants comes under the 41-50 age group and 67 participants comes under 51-60 age group. The majority of respondents belong to 41-50 age groups.

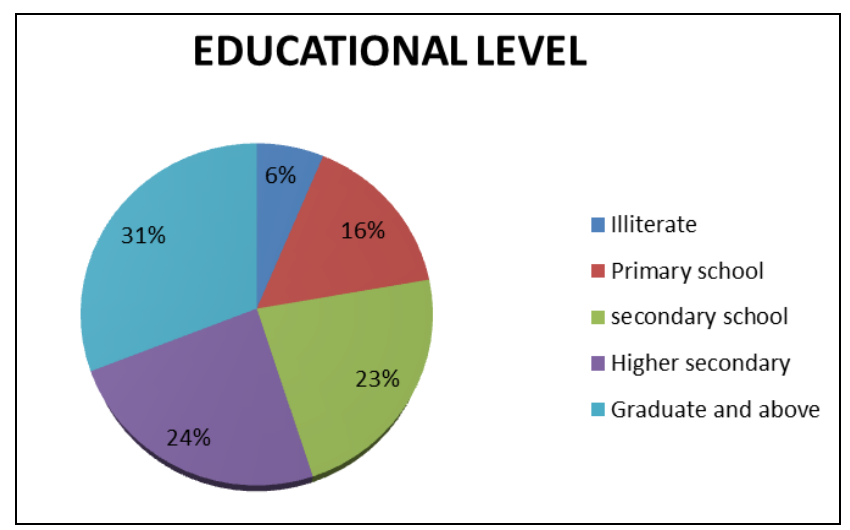

Fig 3: Shows Educational Level distribution

Figure 3 showed as $6 \%$ of participants are illiterate, $16 \%$ of participants are only done primary school, and $23 \%$ of participants are completed. Secondary school, $24 \%$ of participants are completed higher secondary school and remaining $31 \%$ of participants are done graduate and above.

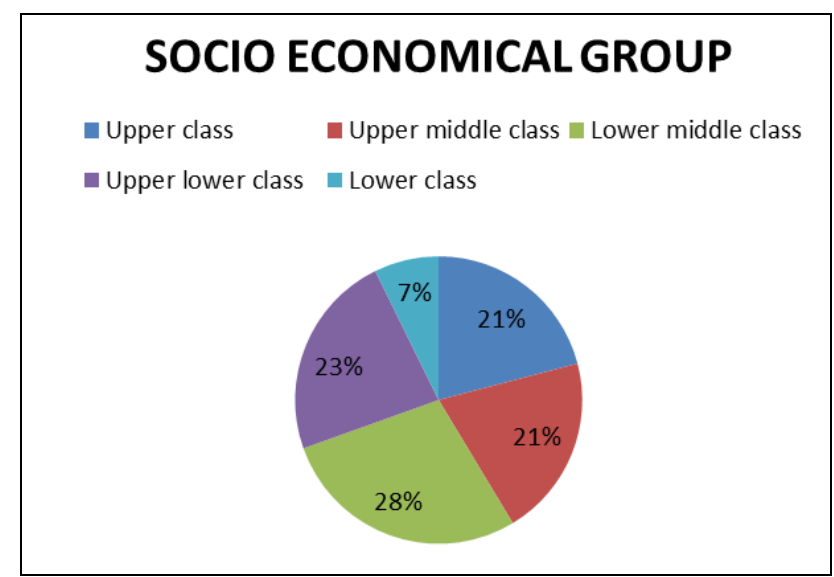

Fig 4: Shows Socio Economical distribution

Figure 4 showed as $7 \%$ of participants are low class, $23 \%$ of participants are upper lower class, $28 \%$ of participants are lower middle class, $21 \%$ of participants are upper middle class and $21 \%$ of participants are upper class. The majority of respondents are lower middle class. 


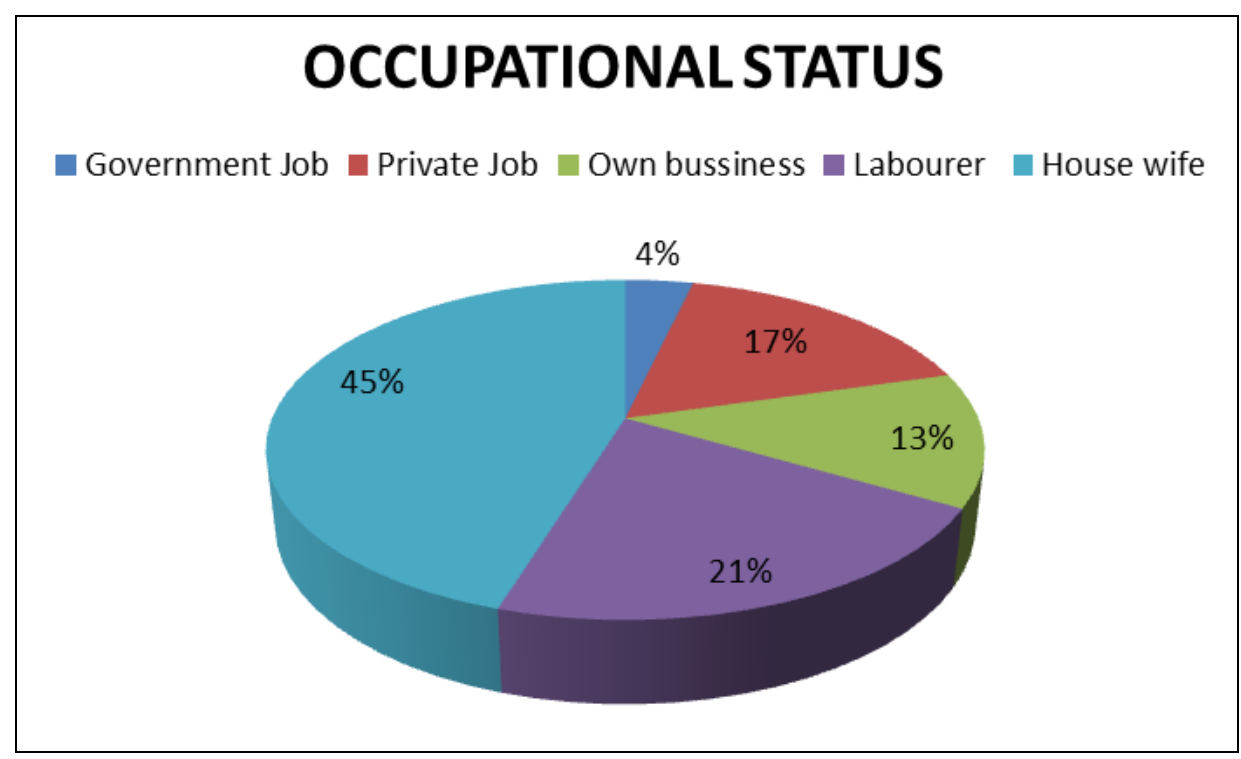

Fig 5: Shows Occupational distribution

Figure 5 showed as $4 \%$ of participants are working government job, $17 \%$ of participants are working private job, $13 \%$ of participants are doing own business, $21 \%$ are doing laborer work and remaining $45 \%$ of participants are housewife. The majority of respondents are housewife.

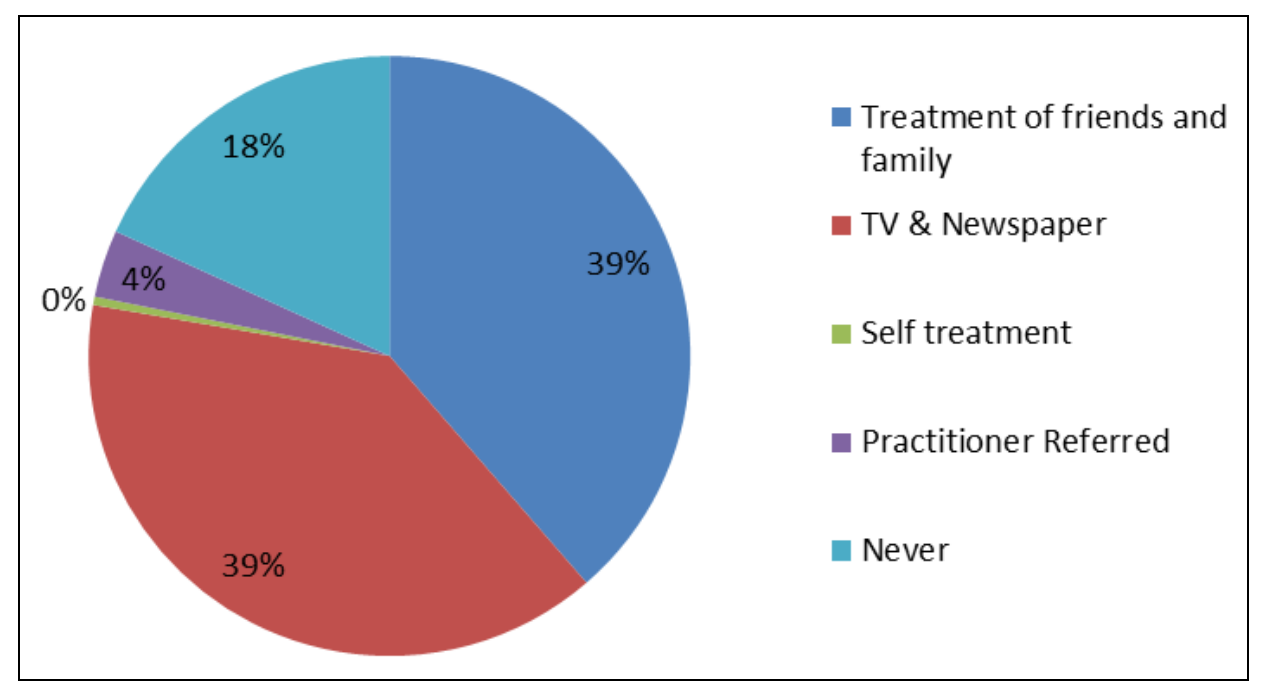

Fig 6: How Did You Learn About Homeopathy?

Figure 6 showed as the majority of respondents knows about homoeopathy via treatments of friends and family (39\%),

TV \& Newspaper (39\%).

Table 1: Association of sex with Homeopathy treatment seeking behavior

\begin{tabular}{|c|c|c|c|c|c|c|c|}
\hline Knowledge Questions & Sex & Never & Sometimes & Mostly & Always & Total & P-value \\
\hline \multirow{2}{*}{ Have You Ever Taken Homeopathic Medicine? } & Male & 55 & 35 & 2 & 0 & 92 & \multirow{2}{*}{0.013} \\
\cline { 2 - 9 } & Female & 100 & 26 & 2 & 0 & 128 & \\
\hline
\end{tabular}


Table 2: Shows the questions \& options frequency and percentage

\begin{tabular}{|c|c|c|c|c|}
\hline S. No & Questions & Options & Frequency & Percentage \\
\hline 1. & Have You Ever Taken Homeopathic Medicine? & $\begin{array}{l}\text { 1. Never } \\
\text { 2. Sometimes } \\
\text { 3. Mostly } \\
\text { 4. Always } \\
\end{array}$ & $\begin{array}{c}155 \\
61 \\
4 \\
0 \\
\end{array}$ & $\begin{array}{c}70.5 \\
27.7 \\
1.8 \\
0 \\
\end{array}$ \\
\hline 2. & Do Homoeopathic Medicines Work? & $\begin{array}{l}\text { 1. Yes } \\
\text { 2. Increases the Disease } \\
\text { 3. Sometimes It Works } \\
\text { 4. Never } \\
\text { 5. Don't Know }\end{array}$ & $\begin{array}{c}97 \\
26 \\
43 \\
0 \\
54\end{array}$ & $\begin{array}{c}44.1 \\
11.8 \\
19.5 \\
0 \\
24.5\end{array}$ \\
\hline 3. & Homeopathic Medicine Can Be Used For? & $\begin{array}{l}\text { 1. Only Children } \\
\text { 2. Only Women } \\
\text { 3. All Age Group } \\
\text { 4. Only Old Age } \\
\text { 5. Don't Know }\end{array}$ & $\begin{array}{c}4 \\
41 \\
45 \\
80 \\
50\end{array}$ & $\begin{array}{c}1.8 \\
18.6 \\
20.5 \\
36.4 \\
22.7\end{array}$ \\
\hline 4. & $\begin{array}{l}\text { For Which Disease Homeopathic Medicine Can } \\
\text { Be Given? }\end{array}$ & $\begin{array}{l}\text { 1. Skin Disease } \\
\text { 2. Joint Pain } \\
\text { 3. All Disease } \\
\text { 4. Except Emergency } \\
\text { 5. Don't Know }\end{array}$ & $\begin{array}{l}13 \\
84 \\
50 \\
26 \\
47\end{array}$ & $\begin{array}{c}5.9 \\
38.2 \\
22.7 \\
11.8 \\
21.4\end{array}$ \\
\hline 5. & $\begin{array}{c}\text { Can Homeopathic Medicines Be Simultaneously } \\
\text { Used With Allopathic Medicine? }\end{array}$ & $\begin{array}{l}\text { 1. Yes } \\
\text { 2. No } \\
\text { 3. Don't Know }\end{array}$ & $\begin{array}{c}2 \\
140 \\
78 \\
\end{array}$ & $\begin{array}{c}0.9 \\
63.6 \\
35.5\end{array}$ \\
\hline 6. & Does homeopathic medicine have side effect? & $\begin{array}{l}\text { 1. Yes } \\
\text { 2. No } \\
\text { 3. Don't Know } \\
\text { 4. To Some extent }\end{array}$ & $\begin{array}{l}27 \\
76 \\
94 \\
23 \\
\end{array}$ & $\begin{array}{l}12.3 \\
34.5 \\
42.7 \\
10.5\end{array}$ \\
\hline 7. & Are All Homeopathic Medicines alike? & $\begin{array}{l}\text { 1. Yes } \\
\text { 2. No } \\
\text { 3. Don't Know }\end{array}$ & $\begin{array}{c}100 \\
54 \\
66 \\
\end{array}$ & $\begin{array}{l}45.5 \\
24.5 \\
30.0 \\
\end{array}$ \\
\hline 8. & $\begin{array}{l}\text { Is Homeopathic Medicine Always Taken In } \\
\text { Empty Stomach? }\end{array}$ & $\begin{array}{l}\text { 1. Yes } \\
\text { 2. No } \\
\text { 3. Don't know }\end{array}$ & $\begin{array}{c}36 \\
117 \\
67\end{array}$ & $\begin{array}{l}16.4 \\
53.2 \\
30.5\end{array}$ \\
\hline 9. & $\begin{array}{c}\text { How Many Persons In Your Adjourning Areas use } \\
\text { Homeopathic Medicine And Are Aware Of It? }\end{array}$ & $\begin{array}{l}\text { 1. No one } \\
\text { 2. Few person } \\
\text { 3. Many } \\
\text { 4. All }\end{array}$ & $\begin{array}{c}41 \\
179 \\
0\end{array}$ & $\begin{array}{c}18.6 \\
81.4 \\
0\end{array}$ \\
\hline 10. & Is Homeopathic Safe For Children? & $\begin{array}{l}\text { 1. Yes } \\
\text { 2. No } \\
\text { 3. Don't know }\end{array}$ & $\begin{array}{l}78 \\
59 \\
83\end{array}$ & $\begin{array}{l}35.5 \\
26.8 \\
37.7 \\
\end{array}$ \\
\hline 11. & $\begin{array}{l}\text { Are Homeopathic Medicines Available Free Of } \\
\text { Cost in Government Hospital Dispensaries? }\end{array}$ & $\begin{array}{l}\text { 1. Yes } \\
\text { 2. No } \\
\text { 3. Don't Know }\end{array}$ & $\begin{array}{c}4 \\
109 \\
107\end{array}$ & $\begin{array}{c}1.8 \\
49.5 \\
48.6\end{array}$ \\
\hline 12. & $\begin{array}{l}\text { Are Homeopathic Medicines Highly Helpful For } \\
\text { Problems During Dentition Among Children? }\end{array}$ & $\begin{array}{l}\text { 1. Yes } \\
\text { 2. No } \\
\text { 3. Don't Know }\end{array}$ & $\begin{array}{c}0 \\
91 \\
129\end{array}$ & $\begin{array}{c}0 \\
41.4 \\
58.6\end{array}$ \\
\hline 13. & Length Of Time In Homeopathic Treatment? & $\begin{array}{l}\text { 1. Not Applicable } \\
\text { 2.1- } 2 \text { Months } \\
\text { 3.3-4 Months } \\
\text { 4.5-6months } \\
\text { 5. More Than 6 Month } \\
\text { 6. More Than } 12 \text { Month }\end{array}$ & $\begin{array}{l}36 \\
41 \\
49 \\
38 \\
36 \\
20\end{array}$ & $\begin{array}{c}16.4 \\
18.6 \\
22.3 \\
17.3 \\
16.4 \\
9.1\end{array}$ \\
\hline 14. & $\begin{array}{l}\text { How Important Has Homeopathy Been In Your } \\
\text { Over All Health Care? }\end{array}$ & $\begin{array}{l}\text { 1. Extreme Important } \\
\text { 2. Very Important } \\
\text { 3. Moderate Important } \\
\text { 4. Slightly Important } \\
\text { 5. Not At All }\end{array}$ & $\begin{array}{c}4 \\
41 \\
91 \\
71 \\
13 \\
\end{array}$ & $\begin{array}{c}1.8 \\
18.6 \\
41.4 \\
32.3 \\
5.9 \\
\end{array}$ \\
\hline
\end{tabular}

Table 3 showed as $70.5 \%$ of respondents never taken homeopathy medicine, the remaining $27.7 \%$ of respondents sometimes taking and $1.8 \%$ of respondents are mostly taking homeopathy medicine. $44.1 \%$ of respondents were answered that homeopathy medicine is working and $11.8 \%$ of respondents have answered homeopathy medicines which increase the disease. $42.7 \%$ of respondents were answered that they did not know about whether homeopathic medicine having side effects or not and only $34.5 \%$ of the response was homeopathic medicine not having a side effect. $38.2 \%$ of people reported that homeopathic medicine can be given for joint complaints and $36.4 \%$ of respondents reported that old age people are majority can take homeopathy medicine. $63.6 \%$ of respondents replied that homeopathic medicine should not be simultaneously used with allopathic medicine. $37.7 \%$ of people replied that they did not know about whether homeopathic medicine safe for children or not but $35.5 \%$ of people accepted that homeopathic medicine safe 
for children. $45.5 \%$ of people gave that ambiguous statement that all homeopathic medicine is looking similar. $53.2 \%$ of respondents replied that homeopathic medicine should not take before food.

$49.5 \%$ of study people replied homeopathy medicine is not easily assessable and there is no pharmacy in our area and the government also not giving the medicine free of cost and in our area, there is no special department for homeopathic treatment in the government hospital.

$58.6 \%$ of people did not know about homeopathic medicine is useful for problems during dentition among children. In our adjoining area, only a few peoples (81.4\%) awarded homeopathic treatment. In this study area, only $41.4 \%$ of people believed homeopathy medicine only moderately important for our health care settings.

\section{Discussion}

Many types of research have been conducted KAP study of homeopathy among health care professionals but only a few studies carried out to know the treatment-seeking behavior of homeopathy among the semi-urban population. Therefore, a study was designed to collect information of treatment seeking behavior of homeopathy treatment in a semi-urban population to use the data to create awareness about homeopathy treatment among the semi-urban population.

It was observed that most semi-urban population 41-50 age groups of peoples were involved in the study and the majorities $(31 \%)$ of respondents were graduated. Socioeconomically, the majority of them belong to the lowermiddle-class group. Most of the participants were housewives. The majority of respondents know about homeopathy via treatments of friends and family (39\%), TV $\&$ Newspaper (39\%). These are the main source to know about homeopathic treatments.

Minimal of the study people (44.1\%) believed homeopathy medicine is working and it having curative power. But the majority of study peoples replied that homeopathic treatment system is not very common in a few public, indicating the need for more public awareness on it.

The findings of our study demonstrate that (38.2\%) patients who seek homeopathic treatment are primarily those suffering from chronic diseases like joint pain, especially for old age people. Majority of study people (70.5\%) not taking homeopathy due to lack of awareness of homeopathy treatment, lack of government hospital department for homeopathy treatment and non-availability of homeopathy pharmacy.

\section{Conclusion}

We evaluated for the first time to know the treatmentseeking behavior of homeopathy in the semi-urban population. Based on our study, the knowledge and treatment-seeking behavior of homeopathy is lacking in the semi-urban population. So, making awareness among the semi-urban population is prime important. Because in study area, the economically majority of people belong to lower middle income. They needed the most cost-effective treatment to lead a healthy life. Homeopathy medicine is having lesser side effects and the most cost-effective treatment. Homeopathy treatment is effective for both acute and chronic disease and it removes root cause of disease. Homeopathy is friendly to children because medicine is very sweet. Homeopathy medicine is a very effective treatment for problems during dentition for children. Homeopathy medicine can take alone with allopathy medicine. It never produces any adverse reaction. Major lack of awareness is due to lack of availability homeopathy clinics and pharmacies in rural and semi-urban areas. So, increasing the availability helpful for homeopathy easily reaches every corner of the rural and semi-urban area. Future studies should create more awareness and a better understanding of homeopathy treatment among the rural and semi-urban population and every homeopath should take major responsibility to create awareness and helps the people to get better treatment in homeopathy.

\section{Reference}

1. EBSCOhost | 95374111 Awareness and Attitudes Concerning AYUSH among the Villagers of Yamunanagar District Haryana. [Internet]. [cited 2019 Mar 7]. Available from:

https://web.b.ebscohost.com/abstract?direct=true\&profi le $=$ ehost $\&$ scope $=$ site $\&$ authtype $=$ crawler $\&$ jrnl $=0972558$ $\mathrm{X} \& \mathrm{AN}=95374111 \& \mathrm{~h}=$ FgzvJAm8E\%2bJZEPuycG\%2f AWY9IVo3UqLvpUqREwumWpemLPOyiqPMaOHt $\% 2 \mathrm{fh} 7 \mathrm{vSjSZ7h0majaEwn76SnNmyD4Zugw \% 3d \% 3d \&}$ $\mathrm{crl}=\mathrm{c} \&$ resultNs $=$ AdminWebAuth\&resultLocal $=$ ErrCrl NotAuth\&crlhashurl=login.aspx $\% 3$ fdirect $\% 3 \mathrm{dtrue} \% 26$ profile $\% 3$ dehost $\% 26$ scope $\% 3$ dsite $\% 26$ authtype $\% 3$ dcra wler\%26jrnl\%3d0972558X\%26AN\%3d95374111

2. Singhal S, Roy V. Awareness, practice and views about integrating AYUSH in allopathic curriculum of allopathic doctors and interns in a tertiary care teaching hospital in New Delhi, India. J Integr Med. 2018; 16(2):113-9.

3. Amulya Ratna Sahoo1 BP Divya Taneja3, AK Hati5. KNOWLEDGE, ATTITUDE AND PRACTICE OF ANGANWADI WORKERS ON HOMOEOPATHIC FORMULATIONS. 2017 Oct 31 [cited 2019 Mar 8]; Available from:

https://zenodo.org/record/2527435\#.XIIEj8kzbIW 